\title{
Chemical nature of soil humified fractions and their bioactivity
}

\author{
Luciano Pasqualoto Canellas ${ }^{(1)}$ and Arnoldo Rocha Façanha ${ }^{(2)}$
}

\begin{abstract}
(1)Universidade Estadual do Norte Fluminense Darcy Ribeiro, Centro de Ciências e Tecnologias Agropecuárias, Laboratório de Solos, Av. Alberto Lamego, 2000, CEP 28013-602 Campos dos Goytacazes, RJ, Brasil. CNPq fellow. E-mail: canellas@uenf.br (2)UENF, Centro de Biociências e Biotecnologia, Laboratório de Biologia Celular. E-mail: arnoldo@uenf.br
\end{abstract}

\begin{abstract}
The aim of this work was to evaluate the humus composition from an Ultisol from Campos dos Goytacazes, RJ, Brazil. Soil samples of four depths (0-0.05, 0.05-0.10, 0.10-0.20 and 0.20-0.40 m) and its chemical nature were analysed by elemental composition, $\mathrm{E}_{4} / \mathrm{E}_{6}$ ratios and Fourier transformed infrared spectroscopy. The bioactivity of these humified substances was evaluated through their action on maize root growth and $\mathrm{H}^{+}$-ATPase activity of root's microsomes. In topsoil, the content of high condensed alkaline soluble humic substances is greater than that found in the subsuperficial layers. The chemical nature of humic and fulvic acids also varied with the soil depth. The humic acids isolated from the soil samples exhibited higher bioactivity compared with the fulvic acids. Moreover, the results suggest that more condensed humic substances can promote highest stimulation of the microsomal $\mathrm{H}^{+}$-ATPases from maize roots. These data reinforce the concept that the activity of the $\mathrm{H}^{+}$pumps can be used as a biochemical marker for evaluation of humic substances bioactivity.
\end{abstract}

Index terms: fulvic acids, humic acids, $\mathrm{H}^{+}$-ATPase.

\section{Natureza química do húmus do solo e sua bioatividade}

\begin{abstract}
Resumo - O objetivo deste trabalho foi avaliar a composição do húmus de um Argissolo Amarelo de Campos dos Goytacazes, RJ, Brasil. Amostras de solo de quatro profundidades (0-0,05, 0,05-0,10, 0,10-0,20 e 0,20-0,40 m) foram analisados mediante o fracionamento químico da matéria orgânica. As frações ácidos húmicos e fúlvicos foram extraídas e sua natureza química avaliada por meio da composição elementar, relação $\mathrm{E}_{4} / \mathrm{E}_{6}$ e espectroscopia de infravermelho transformada de Fourier. A bioatividade das substâncias húmicas foi avaliada mediante sua ação sobre o crescimento radicular de plântulas de milho e atividade da $\mathrm{H}^{+}$-ATPase da fração microssomal das raízes. Os resultados mostraram que é maior o conteúdo de substâncias húmicas alcalino solúveis mais condensadas na camada superficial do solo. A natureza química dos ácidos húmicos e fúlvicos também variou com a profundidade do solo. Os ácidos húmicos isolados das amostras de solo apresentaram maior bioatividade quando comparados aos ácidos fúlvicos, por meio da avaliação do crescimento radicular e da atividade de bombeamento de $\mathrm{H}^{+}$pela fração microssomal de células das raízes. Os dados reforçam o conceito de que a atividade das bombas de $\mathrm{H}^{+}$pode ser usada como marcador bioquímico da bioatividade das substâncias húmicas.

Termos para indexação: ácidos húmicos, ácidos fúlvicos, $\mathrm{H}^{+}$-ATPase.
\end{abstract}

\section{Introduction}

Although the content of organic matter in tropical soils represent only about $1 \%$ of the soil mass, the humus is one of the most important fractions of these soils. The benefits of soil humus have been summarised by Skjemstad et al. (1998) who stated that it is a source of slow-released nutrient, it has a high sortive and exchange capacity for trace or other metal ions, it improves the physical conditions of the soil, buffer the soil against the rapid changes in reactions and reduces toxicity of natu- ral and synthetic toxic compounds. Moreover, it has also been reported that these substances can stimulate plant growth by the release of bioactive molecules with auxin like activities (Bottomley, 1917; Nardi et al., 1991; Canellas et al., 2002), and can directly affect enzymatic activities in several metabolic pathways (Vaughan et al., 1985; Vaughan \& Malcolm, 1985).

Façanha et al. (2002) have found that humic acids isolated from vermicompost can induce the plasma membrane $\mathrm{H}^{+}$-ATPase activity and root development 
of maize. This effect was studied in detail by Canellas et al. (2002), who described hormonal activity of these humic acids on lateral root development.

The aim of this work was to evaluate the humus composition from an Ultisol from Campos dos Goytacazes, RJ, Brazil.

\section{Material and Methods}

\section{Soil samples}

The soil samples were collected at $0-0.05,0.05-0.10$, $0.10-0.20$, and $0.20-0.40 \mathrm{~m}$ depths from an Ultisol (Argissolo in Brazilian Soil Taxonomy) on the experimental field of Universidade Estadual do Norte Fluminense Darcy Ribeiro from Escola Agrotécnica Estadual Antônio Sarlo, Campos dos Goytacazes, Rio de Janeiro, Brazil. Some characteristics of the soil samples are listed in Table 1.

\section{Humus fractionation}

Humus fractionation was performed by the method of Belchikova-Kononova with the modifications described by Guerra \& Santos (1999). Soil samples were treated with $2 \mathrm{~mol} \mathrm{~L}^{-1} o$-phosphoric acid to separate the free fulvic acids fraction (FFA). Afterwards, the humic fraction was extracted by adding $100 \mathrm{~mL}$ of $0.1 \mathrm{M} \mathrm{NaOH}+0.1 \mathrm{M} \mathrm{Na}_{4} \mathrm{P}_{2} \mathrm{O}_{7}$ to $10 \mathrm{~g}$ sample and shaken for 16 hours at room temperature. The dark-colored supernatant solution was separated from the residual soil by centrifugation at $3,000 \mathrm{~g}$ for $30 \mathrm{~min}$. Soil residue was resuspended in $50 \mathrm{~mL}$ of $0.1 \mathrm{M} \mathrm{NaOH}+0.1 \mathrm{M} \mathrm{Na}_{4} \mathrm{P}_{2} \mathrm{O}_{7}$ then shaken for 4 hours. The solution was centrifuged again and the supernatant was added to the supernatant collected previously. The extracted alkaline solution containing dissolved humic (HA) and fulvic acids (FA) was acidified to $\mathrm{pH} 1.0-1.5$ with concentrated $\mathrm{H}_{2} \mathrm{SO}_{4}$. After 12 hours at $8^{\circ} \mathrm{C}$ the extract was separated into soluble and insoluble parts by centrifugation. After fractionation the content of organic carbon in the soluble humified organic matter (FFA, FA and HA) and in the insoluble residues (humins) was determined by Walkley-Black procedures (Page, 1982).

\section{Extraction, separation and analyse of humic and fulvic acids}

Five hundred grams of air-dry soil were weighed into a $3.5 \mathrm{~L}$ flask, $1.5 \mathrm{~L}$ of $0.5 \mathrm{~mol} \mathrm{~L}^{-1} \mathrm{NaOH}$ was added. The air in the flask and in the solution was displaced by $\mathrm{N}_{2}$ and the system was shaken for 16 hours at room temperature. The dark-colored supernatant solution, after separation from the residual soil by centrifugation (850 $\mathrm{g}$ for $30 \mathrm{~min}$ ) was acidified to $\mathrm{pH} 1.5$ with $6 \mathrm{~mol} \mathrm{~L}^{-1} \mathrm{HCl}$. This extract was placed to rest for 16 hours at room temperature in order to allow the coagulation of their humic acids fraction. The soluble material (fulvic acids) was separated from the humic acids by centrifugation (1,500 $g$ for $20 \mathrm{~min}$ ). The humic acids fraction was dissolved and precipitated three times. Then the humic acids were shaken during 24 hours at room temperature with $40 \mathrm{~mL}$ of $0.5 \%(\mathrm{v} / \mathrm{v}) \mathrm{HCl}-\mathrm{HF}$ solution. The insoluble residues (humic acids) were separated from the supernatant by centrifugation, washed with distilled water until free of $\mathrm{Cl}^{-}$(by $\mathrm{AgNO}_{3}$ test) and freeze dried. The ash content of HA was less than $0.5 \%$. The purification of fulvic acids required the removal of large amount of $\mathrm{NaCl}$. The acid soluble supernatant with this fraction was dried at $40^{\circ} \mathrm{C}$. The residues were dissolved into methanol and concentrated on the rotary evaporator at $40^{\circ} \mathrm{C}$. This extract was redissolved in small volume of distilled water, mixed to $150 \mathrm{~g}$ of Amberlit IRA $-120 \mathrm{H}^{+}$and separated by filtration. The ash content of purified fulvic acids was less than $1 \%$. Elemental composition was determined with a CHN Perkin-Elmer autoanalyser. $\mathrm{E}_{4} / \mathrm{E}_{6}$ ratios were determined by dissolving $1 \mathrm{mg}$ of either HA or FA in $5 \mathrm{~mL}$ of $0.05 \mathrm{M} \mathrm{NaHCO}_{3}$ and the $\mathrm{pH}$ was adjusted to 8.3 with $\mathrm{NaOH}$. The absorbances at $465 \mathrm{~nm}$ and $665 \mathrm{~nm}$ were measured on a Schimadzu spectrophotometer. The ratio between these absorbance corresponded to $\mathrm{E}_{4} / \mathrm{E}_{6}$. Fourier transformed infrared spectroscopy (FT-IR) spectra of HAs were recorded on $\mathrm{KBr}$ pellts in the $4,000-400 \mathrm{~cm}^{-1}$ wave number using a Perkin Elmer 1420 spectrophotometer.

Table 1. Some characteristics of Ultisol from Campos dos Goytacazes, RJ.

\begin{tabular}{ccccccc}
\hline Sample & $\begin{array}{c}\text { Soil depth } \\
(\mathrm{m})\end{array}$ & $\mathrm{pH}\left(\mathrm{H}_{2} \mathrm{O}\right)$ & $\mathrm{C}$ & $\mathrm{N}$ & $\begin{array}{c}\mathrm{C} / \mathrm{N} \\
-----\left(\mathrm{g} \mathrm{kg}^{-1}\right)-----\end{array}$ & $\begin{array}{c}\text { Cation exchange capacity } \\
\left(\mathrm{cmol}_{\mathrm{c}} \mathrm{dm}^{-3}\right)\end{array}$ \\
\hline 1 & $0.00-0.05$ & 5.8 & 10.9 & 1.3 & 8.4 & 3.00 \\
2 & $0.05-0.10$ & 5.7 & 10.4 & 1.2 & 8.7 & 2.90 \\
3 & $0.10-0.20$ & 5.3 & 9.7 & 1.1 & 2.46 \\
4 & $0.20-0.40$ & 5.1 & 7.5 & 1.0 & 7.5 & 2.06 \\
\hline
\end{tabular}




\section{Bioactivity of humified fractions}

A most common variety of maize cultivated by the small farmers of the north region of Rio de Janeiro State, known as "caboclo" maize, was used in his study. This variety is adapted to water stress, a typical condition in soils from this region. In spite of low productivity, the rusticity of this variety ensures the production for subsistence of poor farmers (Altieri, 2002). Four days after germination in pots containing washed sand (three replicate for each treatment), maize seedlings were irrigated daily with a solution of humic and fulvic acids at $40 \mathrm{mg} \mathrm{L}^{-1}$ for seven-days. At the seventh day, roots were collected from ten seedlings for each treatment to estimate their length and superficial area using DELTA-T SCAN software image analyzer. Afterwards mass of dry matter was measured.

Microsomal vesicles were isolated from maize roots by differential centrifugation (De Michelis \& Spanswich, 1986). Briefly, $20 \mathrm{~g}$ of roots were homogenized in a blender with $30 \mathrm{~mL}$ of an ice-cold buffer containing $100 \mathrm{mM} \mathrm{KCl}$, $2 \mathrm{mM}$ DTT, $0.1 \%$ BSA, $1 \mathrm{mM}$ PMSF and $70 \mathrm{mM}$ Tris$\mathrm{HCl}$ buffer ( $\mathrm{pH} 8.0)$. The homogenate was strained through four layers of cheesecloth and centrifuged at $1,500 \mathrm{~g}$ for $15 \mathrm{~min}$. Then, the supernatant was centrifuged at $10,000 \mathrm{~g}$ for $15 \mathrm{~min}$ and centrifuged again at $100,000 \mathrm{~g}$ for $30 \mathrm{~min}$. The pellet was resuspended in a $1 \mathrm{~mL}$ of ice-cold buffer containing $10 \mathrm{mM}$ Tris- $\mathrm{HCl}$ (pH 7.6), 20\% (v/v) glycerol, $1 \mathrm{mM}$ DTT and $1 \mathrm{mM}$ PMSF.

The vesicles of microsomal preparation were then frozen under liquid nitrogen and stored at $-20^{\circ} \mathrm{C}$ until use. Protein concentration was determined by the method of Bradford using BSA as a standard (Bradford, 1976). The accumulation of protons inside the membrane vesicles was determined by measuring the fluorescence quenching of ACMA with an Hitachi F 4500 fluorometer. The excitation and emission wavelengths were set at
415 and 485 nm, respectively (Façanha \& De Meis, 1995). The composition of the reaction medium was $10 \mathrm{mM}$ Mops-tris buffer (pH 6.5), 2 mM ACMA and $0.2 \mathrm{mg} \mathrm{mL}^{-1}$ microsomal protein. The reaction was started by the addition of $1 \mathrm{mM}$ ATP and performed at $25^{\circ} \mathrm{C}$.

\section{Results and Discussion}

The acid-soluble fraction less condensed consisting in free fulvic acids (FFA) varied from 10 to $8 \%$ of the total organic carbon (Table 2). The alkali-soluble fulvic acid (FA) content was higher compared with the FFA fraction. On the other hand, the humic acid (HA) concentration was higher at the topsoil (Table 2). This is in agreement with data obtained in other Ultisols (Canellas et al., 2000). Orlov (1998) suggested that the highest biological activity on the surface probably promotes the formation of condensed alkali-soluble humic substances with greater stability. In the same way, a larger HA/FA ratio was found at the surface (Table 2). The HA/FA ratio was used by Kononova (1982) as an indicator of the humus quality. The low content of exchangeable bases in the soil may also decrease the intensity of the humification process, i.e., microbial and chemical condensation and synthesis reactions (Stevenson, 1994). As a result, the HA/FA ratio is smaller in strong weathering soils.

Although the soil organic matter exhibits a fulvatic character, the humification rate was quite high varying from 96 to $83 \%$ of soil organic carbon (Table 2). This is probably due to the stabilization of organic compounds via association with the mineral fraction and/or the preservation of nonpolar substances in the humic fraction (Dabin, 1981). Contents of humins found were within the range of values considered by Dabin (1981), who classified them from strong to very strong, which is a

Table 2. Mean of C content of different fractions of humified organic matter of Ultisol samples from Campos dos Goytacazes, $\mathrm{RJ}^{(1)}$.

\begin{tabular}{lccccccc}
\hline Sample & $\begin{array}{c}\text { Soil depth } \\
(\mathrm{m})\end{array}$ & Free fulvic acid & Fulvic acid & $\begin{array}{c}\text { Humic acid } \\
-\end{array}$ & Humins & HA/FA & $\begin{array}{c}\text { Humification degree } \\
(\%)\end{array}$ \\
\hline 1 & $0.00-0.05$ & $1.13 \mathrm{~A}$ & 2.10 & $1.84 \mathrm{~A}$ & $5.38 \mathrm{~A}$ & $0.60 \mathrm{~A}$ & 96 \\
2 & $0.05^{-0.10}$ & $1.02 \mathrm{AB}$ & 2.21 & $1.11 \mathrm{~B}$ & $5.16 \mathrm{~A}$ & $0.33 \mathrm{~B}$ & 91 \\
3 & $0.10^{-0.20}$ & $0.93 \mathrm{~B}$ & 2.44 & $0.87 \mathrm{~B}$ & $3.99 \mathrm{~B}$ & $0.27 \mathrm{~B}$ & 85 \\
4 & $0.20^{-} 0.40$ & $0.57 \mathrm{C}$ & 1.51 & $0.20 \mathrm{C}$ & $3.96 \mathrm{~B}$ & $0.10 \mathrm{C}$ & 83 \\
\hline F & & $12.82^{* *}$ & $2.97^{\text {ns }}$ & $27.22^{* *}$ & $31.26^{* *}$ & $27.04^{* *}$ & \\
CV $(\%)$ & & 12.89 & 19.25 & 22.29 & 5.04 & 21.78 & \\
\hline
\end{tabular}

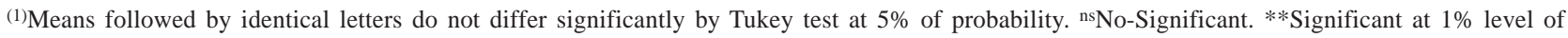
probability. 
characteristic of tropical environments. In this study the observed accumulation of humins at soil surface may be explained by a continuous process of transformation from alkali-soluble to insoluble organic compounds.

The $\mathrm{C}$ content of alkaline soluble humic substances ranged from 19.51 to $32.32 \mathrm{~g} \mathrm{~kg}^{-1}$, while the $\mathrm{C}$ values of FA varied from 12.89 to $21.44 \mathrm{~g} \mathrm{~kg}^{-1}$ and the values decreased with soil depth (Table 3 ). The $\mathrm{C}$ content in both humic substances was lower than normally found in other tropical soils and it is an indicative of low intensity of humification process in this soil (Stevenson, 1994). Further, the $\mathrm{H}$ content ranged from 26.50 to $32.25 \mathrm{~g} \mathrm{~kg}^{-1}$ and from 26.71 to $32.33 \mathrm{~g} \mathrm{~kg}^{-1}$ to HA and FA, respectively (Table 3 ) and were four to eight-fold higher than the values determined for other soils (Canellas et al., 2001). The high content of $\mathrm{H}$ can indicate an abundance of $\mathrm{sp}^{3} \mathrm{C}$ in humic substances (Preston, 1996). The $\mathrm{N}$ content of humic acids ranged from 0.59 to 1.38 and increased following the sequence HA-2<HA-4<HA-3<HA-1 and FA-4<FA-3<FA-2<FA-1. The $\mathrm{N}$ content of fulvic acid fraction decreased systematically with soil depth (Table 3 ).

Atomic ratios $\mathrm{O} / \mathrm{C}, \mathrm{H} / \mathrm{C}$ and $\mathrm{C} / \mathrm{N}$ are often used to identify humic substances from different sources and to follow their structural changes in different environments (Steelink, 1985). The O/C ratios is considered an indicator of carbohydrate and carboxylic contents of humic substances and can be used to compare HA and FA. The $\mathrm{O} / \mathrm{C}$ ratio is also a representative of the degree of humification. A decrease of this ratio commonly suggests an increase in the aromatic condensation. By comparing the $\mathrm{O} / \mathrm{C}$ ratio of $\mathrm{HA}$ and $\mathrm{FA}$ from different soil depths, a progressive decrease in aromaticity from depth suggest that the maturity of HS is higher in topsoil. The value of $\mathrm{H} / \mathrm{C}$ ratios shows the degree of maturity in humic substances (Gonzales-Vila et al., 1992; Lu et al., 2000.) since indirectly it reflects the existence of more condensed aromatic ring or substituted ring structures.

The HA isolated from topsoil $(0,0-0,05 \mathrm{~m})$ showed the smaller $\mathrm{H} / \mathrm{C}$ ratio. In turn, FA presented a linear enhance on $\mathrm{H} / \mathrm{C}$ ratio with increase of soil depth. According to Baranciková et al. (1997) the diagram of $\mathrm{H} / \mathrm{C}$ atomic ratio against $\mathrm{O} / \mathrm{C}$ atomic ratio may be considered as a graphical-statistical representation which indicates the changes in properties occurring during coalification reactions such as oxidation, dehydrogenation, dehydration, demethanation and decarboxylation. The linear relationship of $\mathrm{H} / \mathrm{C}$ atomic ratio against $\mathrm{O} / \mathrm{C}$ atomic ratio of humic and fulvic acids (Figure 1) suggest that microbial degradation may be more significant than chemical degradation in the soil during humification process (Lu et al., 2000).

$\mathrm{E}_{4} / \mathrm{E}_{6}$ ratios were determined by sample absorbance at 465 and $665 \mathrm{~nm}$. Despite considerable discussion, the significance of optical properties of humic substances is still not fully understood, and in some respects is controversial. However, considerable evidence indicates that lower $\mathrm{E}_{4} / \mathrm{E}_{6}$ ratios values are associated with more mature humic and fulvic acid fractions characterized by more abundant aromatic components and a higher degree of condensation (Kononova, 1982). However, Chen et al. (1977) found no relation between the $\mathrm{E}_{4} / \mathrm{E}_{6}$ ratios and the degree of aromaticity but observed inverse relationship with molecular weight for humic substances.

Table 3. Elemental composition, atomic ratios and $\mathrm{E}_{4} / \mathrm{E}_{6}$ ratios of humic (HA) and fulvic acids (FA) isolated from Ultisol samples in Campos dos Goytacazes, RJ.

\begin{tabular}{|c|c|c|c|c|c|c|c|c|c|}
\hline Sample & $\begin{array}{c}\text { Depth } \\
(\mathrm{m})\end{array}$ & $\mathrm{C}$ & H & ------ & ---- & $\mathrm{H} / \mathrm{C}$ & $\mathrm{O} / \mathrm{C}$ & $\mathrm{C} / \mathrm{N}$ & $\mathrm{E}_{4} / \mathrm{E}_{6}$ \\
\hline & & \multicolumn{8}{|c|}{ Humic acid fraction } \\
\hline 1 & $0.00-0.05$ & 32.32 & 29.75 & 1.16 & 36.77 & 0.92 & 1.14 & 27.84 & 4.4 \\
\hline 2 & $0.05-0.10$ & 24.19 & 32.95 & 0.59 & 42.27 & 1.36 & 1.75 & 40.98 & 4.0 \\
\hline 3 & $0.10^{-}-0.20$ & 22.04 & 30.22 & 1.00 & 46.74 & 1.37 & 2.12 & 21.96 & 5.8 \\
\hline 4 & $0.20-0.40$ & 19.51 & 26.50 & 0.78 & 53.21 & 1.36 & 2.73 & 25.08 & 7.0 \\
\hline \multicolumn{10}{|c|}{ Fulvic acid fraction } \\
\hline 1 & $0.00-0.05$ & 21.44 & 32.33 & 1.38 & 44.84 & 1.51 & 2.09 & 15.56 & 7.8 \\
\hline 2 & $0.05-0.10$ & 18.57 & 31.15 & 1.18 & 49.09 & 1.68 & 2.64 & 15.68 & 8.7 \\
\hline 3 & $0.10^{-}-0.20$ & 14.43 & 28.09 & 0.92 & 56.56 & 1.95 & 3.92 & 15.69 & 7.2 \\
\hline 4 & $0.20-0.40$ & 12.89 & 26.71 & 0.81 & 59.60 & 2.07 & 4.63 & 15.90 & 9.7 \\
\hline
\end{tabular}


Also these authors showed that $\mathrm{E}_{4} / \mathrm{E}_{6}$ ratios correlated with $\% \mathrm{C}, \% \mathrm{O}$, acidity and amount of $\mathrm{COOH}$ groups. In this study $\mathrm{E}_{4} / \mathrm{E}_{6}$ values for humic acids ranged from $4.0-7.0$ with the increase $\left(\mathrm{r}^{2}=0.90\right)$ of depth. For fulvic acids $\mathrm{E}_{4} / \mathrm{E}_{6}$ ranged from 7.2-9.7 and the correlation with soil depth was not significant $\left(\mathrm{r}^{2}=0.40\right)$ probably due to the mobility of this soluble fraction. This behaviour was observed in another tropical soil (Griffth \& Schnitzer, 1975). The accumulation of relatively immature humic acids with higher $\mathrm{E}_{4} / \mathrm{E}_{6}$ at $0.10-0.20 \mathrm{~m}$ and $0.20-0.40 \mathrm{~m}$ is probably associated with constraints on microbiological activity and hence humus synthesis (Figure 1).

Several characteristic absorptions can be detected in the infrared spectra of humic and fulvic acids (Figure 2). The spectra of humic acids share in common a strong and large absorption band at $3,300 \mathrm{~cm}^{-1}$ due to $\mathrm{O}-\mathrm{H}$ groups and $\mathrm{N}-\mathrm{H}$ stretching; antisymmetrical and symmetrical stretching of $\mathrm{C}-\mathrm{H}$ aliphatic groups absorption at 2,968 and 2,971 $\mathrm{cm}^{-1}$; the absorption band at $1,733 \mathrm{~cm}^{-1}$ may be due to $\mathrm{C}=\mathrm{O}$ in carbonyl groups; the carbonyl stretching mode of secondary amides such as
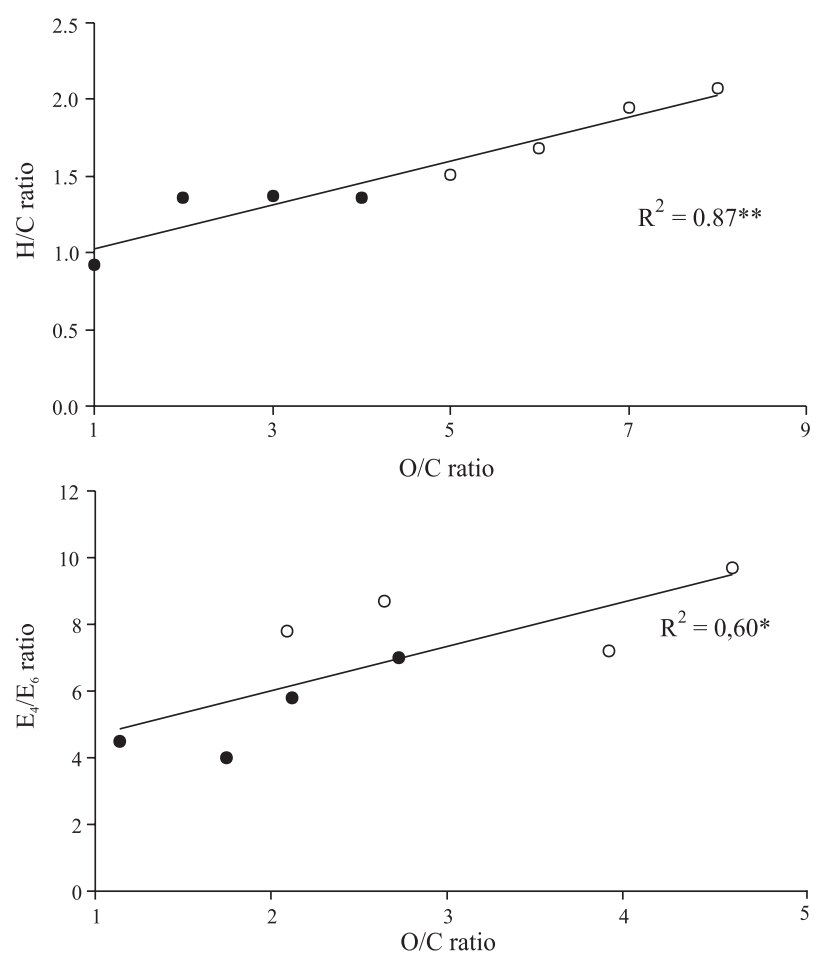

Figure 1. Relationship between $\mathrm{O} / \mathrm{C}$ atomic ratios and $\mathrm{H} / \mathrm{C}$ ratios and $\mathrm{E}_{4} / \mathrm{E}_{6}$ ratios from fulvic $(\mathrm{O})$ and humic acids $(\bullet)$, of an Ultisol. those occurring in proteins and polypeptides is referred to Amide I band and occurred near $1,654 \mathrm{~cm}^{-1}$.

Secondary amides also exhibit another characteristics band (Amide II) at $1,540 \mathrm{~cm}^{-1}$ assignable as the N-H deformation mode (Coulthup et al., 1964). The absorption bands at $1,600 \mathrm{~cm}^{-1}$ is characteristic from skeletal stretching mode of the semiunsaturated C-C bonds of an aromatic ring. The ionised carboxyl group occurred between 1,610 and 1,550 $\mathrm{cm}^{-1}$ and between 1,450 and $1,300 \mathrm{~cm}^{-1}$ and corresponds to the antisymmetrical and symmetrical vibrations of $\mathrm{COO}^{-}$structure. Absorption bands at $1,237 \mathrm{~cm}^{-1}$ were attributed to phenol deformations; absorptions due to the $\mathrm{C}-\mathrm{O}$ stretching mode of polysaccharides exhibited strong band near

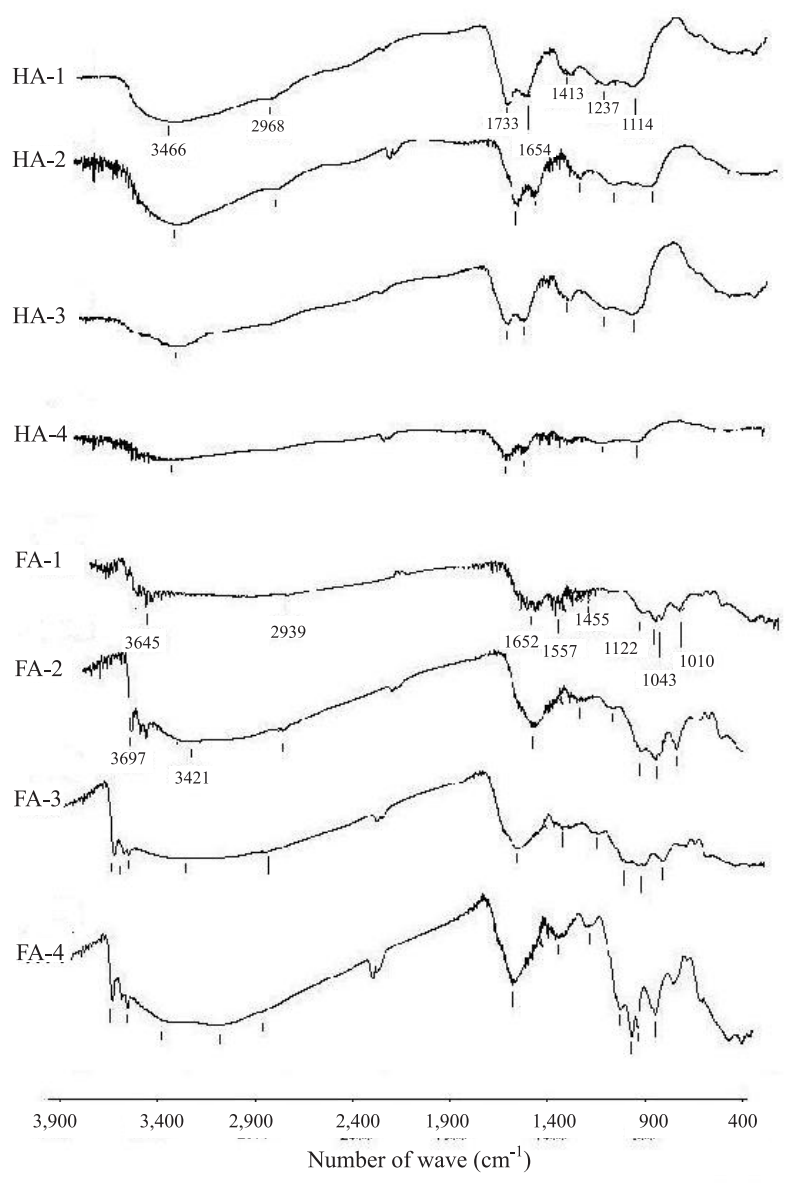

Figure 2. Infrared spectra from humic (HA) and fulvic acids (FA) isolated from Ultisol samples of Campos dos Goytacazes, RJ, collected at soil depths $1(0.00-0.05 \mathrm{~m}), 2(0.05-0.10 \mathrm{~m})$, $3(0.10-0.20 \mathrm{~m})$ and $4(0.20-0.40 \mathrm{~m})$. 
$1,114 \mathrm{~cm}^{-1}$. The bands at $799-800 \mathrm{~cm}^{-1}$ were attributed to $\mathrm{Si}-\mathrm{O}$ and $\mathrm{O}-\mathrm{Al}-\mathrm{OH}$ and/or O-Fe-OH vibrations. All spectra analyzed can be classified as Type III spectra according to Stevenson classification (Stevenson, 1994). In the fulvic acids additional absorption band was observed at $3,645 \mathrm{~cm}^{-1}$ due N-H or O-V stretching of free groups; the absence of $\mathrm{C}=\mathrm{O}$ vibrations at $1,700 \mathrm{~cm}^{-1}$ and the presence of secondary amides (Amide I at 1,652 $\mathrm{cm}^{-1}$ and Amide II at $1,540 \mathrm{~cm}^{-1}$ ). At different depth, the main differences between IR-FT spectra from HA were found in the intensity of absorption at $3,460 \mathrm{~cm}^{-1}$ that decreased with soil depth. No great TF-IR spectra from fulvic acids with soil depth were observed.

Both humic and fulvic acids stimulated maize root superficial area with an average increase of $56 \%$ for humic acids and $31 \%$ for fulvic acids (Table 4 ). However, only treatment with humic acids isolated at $0.05-0.10 \mathrm{~m}$ was statistically significant in comparison to the control plants. The total root length (calculated as a sum of all root segments) and radicular dry matter were not affected by the treatments. The rates of initial $\mathrm{H}^{+}$ gradient were greater in preparations from roots treated with humic acids (220\% stimulation in average) compared to those treated with fulvic acids fraction(117\% stimulation) (Table 4). The stimulation of $\mathrm{H}^{+}$pumping by humic acids was in order HA-2>HA-1>HA-3>HA-4, i.e., the greater stimulation was obtained with humic acids isolated from top soil
$(0-0.10 \mathrm{~m})$ and corresponded to the humic acids fractions with more condensed chemical nature. The order of $\mathrm{H}^{+}$pumping stimulation was FA-3>FA-1>FA-2 for the fulvic acids fraction. The fulvic acid fraction isolated from $0.20-0.40 \mathrm{~m}$ (FA-4) inhibited the $\mathrm{H}^{+}$ gradient and resulted in smaller root development. No direct relationship was found between the stimulation of $\mathrm{H}^{+}$pumping by fulvic fraction with the soil depth probably due to the high mobility of this humified fraction in soil profile. However, the relationship between the promotion of $\mathrm{H}^{+}$pumping by fulvic acids and their chemical nature evaluated by $\mathrm{E}_{4} / \mathrm{E}_{6}$ was analogous to that observed for humic acids fraction. For both HA and FA a more condensed structure was associated with the highest rates of $\mathrm{H}^{+}$pumping (Figure 3).

The highest bioactivity was found in the soil surface layers $(0-0.1 \mathrm{~m})$ associated with the more condensed HA (Tables 3 and 4). Indeed, the superficial layer of soils is often considered the most fertile, but this fertility is mainly correlated with the higher nutrient content of this layer (Tisdale \& Nelson, 1966). The stimulation of both $\mathrm{H}^{+}$pumping and root superficial area promoted by these HA suggest that the $\mathrm{H}^{+}$-ATPase activity can be used as a biochemical marker of humic substances bioactivity in soils. Moreover, this HA exhibited more complex structure as revealed by $\mathrm{E}_{4} / \mathrm{E}_{6}$ ratio (Table 3), which is in agreement with the idea that humic substances with complex structure clustered bioactive molecules that can be released during an interplay with plant roots, resulting

Table 4. Effects of humic (HA) and fulvic acids (FA) on maize root growth and $\mathrm{H}^{+}$pumping in microsomal vesicles.

\begin{tabular}{|c|c|c|c|c|c|c|}
\hline \multirow[t]{2}{*}{ Sample } & \multirow{2}{*}{$\begin{array}{l}\text { Depth } \\
(\mathrm{m})\end{array}$} & \multirow{2}{*}{$\begin{array}{l}\text { Superficial area } \\
\qquad\left(\mathrm{mm}^{2}\right)\end{array}$} & \multirow{2}{*}{$\begin{array}{c}\text { Total length } \\
\text { (mm) }\end{array}$} & \multirow{2}{*}{$\begin{array}{c}\text { Dry mass } \\
\text { (g) }\end{array}$} & \multicolumn{2}{|c|}{$\begin{array}{l}\mathrm{H}^{+} \text {pumping by root vesicles } \\
\text { of microssomal preparation }\end{array}$} \\
\hline & & & & & $\min (\%)$ & $\ddot{\mathrm{A} F}(\%)^{(2)}$ \\
\hline & & \multicolumn{5}{|c|}{ Humic acid fraction } \\
\hline Control & - & $28.81 \mathrm{C}$ & 10,911 & 0.0458 & 3.8 & 24.0 \\
\hline 1 & $0.00-0.05$ & $36.44 \mathrm{BC}$ & 9,197 & 0.0508 & 14.0 & 27.2 \\
\hline 2 & $0.05-0.10$ & $58.76 \mathrm{~A}$ & 7,804 & 0.0493 & 16.0 & 28.9 \\
\hline 3 & $0.10^{-}-0.20$ & $38.22 \mathrm{BC}$ & 6,835 & 0.0505 & 11.0 & 36.6 \\
\hline 4 & $0.20-0.40$ & $46.49 \mathrm{AB}$ & 7,799 & 0.0555 & 8.0 & 30.5 \\
\hline & & \multicolumn{5}{|c|}{ Fulvic acid fraction } \\
\hline 1 & $0.00-0.05$ & $47.06 \mathrm{AB}$ & 7,039 & 0.0530 & 8.0 & 30.4 \\
\hline 2 & $0.05^{-}-0.10$ & $37.29 \mathrm{BC}$ & 7,184 & 0.0398 & 5.2 & 10.9 \\
\hline 3 & $0.10^{-}-0.20$ & $34.92 \mathrm{BC}$ & 6,034 & 0.0388 & 11.5 & 22.4 \\
\hline 4 & $0.20^{-} 0.40$ & $32.04 \mathrm{C}$ & 6,027 & 0.0365 & 0.0 & 0.0 \\
\hline $\mathrm{F}$ & - & 4.87 ** & $0.48^{\mathrm{ns}}$ & $1.54^{\mathrm{ns}}$ & - & - \\
\hline $\mathrm{CV}(\%)$ & - & 25.6 & 72.3 & 28.75 & - & - \\
\hline
\end{tabular}

${ }^{(1)}$ Means followed by identical letters do not differ significantly by Tukey test at $5 \%$ of probability. ${ }^{(2)}$ Arbitrary unit of fluorescence. ns No-significant. ${ }^{*}$ Significant at $1 \%$ level of probability. 


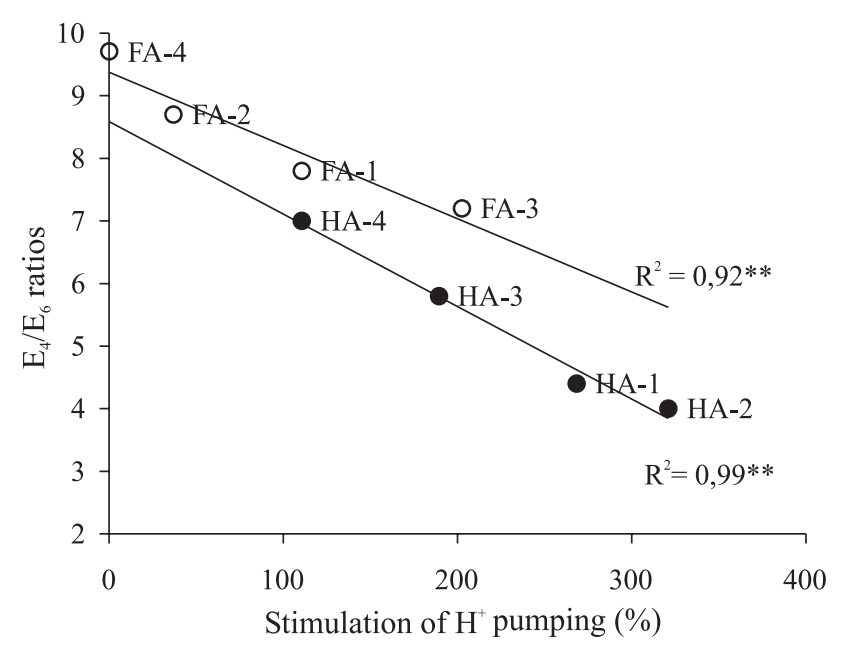

Figure 3. Relationship between structural parameters of humic acids $(\bullet)$ and fulvic acids $(\mathrm{O})$ provided by $\mathrm{E}_{4} / \mathrm{E}_{6}$ ratio and their effect on $\mathrm{H}^{+}$pumping of maize roots membrane vesicles.

in the activation of receptors, enzymes and signalling pathways (Canellas et al., 2002; Façanha et al., 2002).

\section{Conclusions}

1. The distribution of humified fraction from soil organic matter is typical for the tropical soils with high content of insoluble fraction and predominance of fulvic acids in alkali-soluble extracts.

2. There are clear differences in the chemical nature and functionality of fulvic and humic acids depending on the soil depth.

3. The results suggest that more condensed humic substances can promote highest stimulation of the microssomal $\mathrm{H}^{+}$-ATPases from maize roots.

4. These data reinforce the idea that the activity of the plasma membrane $\mathrm{H}^{+}$pumps can be used as a biochemical marker for humic substances bioativity.

\section{Acknowledgements}

To the International Foundation of Science (C-3391-1 and C-3483-1), Conselho Nacional de Desenvolvimento Científico e Tecnologico (471910/2003-1) and Fundação Carlos Chagas Filho de Amparo à Pesquisa do Rio de Janeiro for financial support; to Dra. Anna Okorokova-Façanha (Universidade Estadual do Norte Fluminense) for revision and helpful discussion of the manuscript.

\section{References}

ALTIERI, M.A. Agroecology: the science of natural resource management for poor farmers in marginal environments. Agriculture, Ecosystems and Environment, v.93, p.1-24, 2002.

BARANCIKOVÁ, G.; SENESI, N.; BRUNETTI, G. Chemical and spectroscopic characterization of humic acids isolated from different Slovak soil types. Geoderma, v.78, p.251-266, 1997.

BOTTOMLEY, W.B. Some effects of organic-promotion substances (auximones) on the growth of Lema minor in mineral cultural solutions. Proceedings of the Royal Society of London, Series B Biological Sciences, v.89, p.481-505, 1917.

BRADFORD, M. A rapid and sensitive method for the quantitation of microgram quantities of protein utilizing the principle of proteindye binding. Analytical Biochemistry, v.72, p.248-254, 1976.

CANELLAS, L.P.; BERNER, P.G.; SILVA S.G. da; SILVA, M.B.E.; SANTOS, G. de A. Organic matter fractions in a toposequence of six soils in the State of Rio de Janeiro, Brazil. Pesquisa Agropecuária Brasileira, v.35, p.133-143, 2000.

CANELlAS, L.P.; FAÇANHA, A.O.; OLIVARES, F.L.; FAÇANHA, A.R. Humic acids isolated from earthworm compost enhance root elongation, lateral root emergence, and plasma membrane $\mathrm{H}^{+}$-ATPase activity in maize roots. Plant Physiology, v.130, p.19511957, 2002.

CANELLAS, L.P.; SANTOS, G de A.; RUMJANEK, V.M.; MORAES, A.A.; GURIDI, F. Distribution of the organic matter and humic acid characteristic in soils with addition of residues of urban origin. Pesquisa Agropecuária Brasileira, v.36, p.1529-1538, 2001.

CHEN, Y.; SENESI, N.; SCHNITZER, M. Information provide on humic substances by $\mathrm{E}_{4} / \mathrm{E}_{6}$ ratios. Soil Science Society of America Journal, v.41, p.352-358, 1977.

COULTHUP, N.B.; DALY, L.H.; WIBERLEY, S.E. Introduction to infrared and raman spectroscopy. New York: Academic, 1964. $511 \mathrm{p}$.

DABIN, B. Les matièrie organiques dans les sols tropicaux normalement drainés. Cahiers ORSTOM, v.28, p.197-217, 1981.

DE MICHELIS, M.I.; SPANSWICH, R.M. $\mathrm{H}^{+}$-pumping driven by vanadate sensitive ATPase in membrane vesicles from corn roots. Plant Physiology, v.81, p.542-547, 1986.

FAÇANHA, A.R; DE MEIS, L. Inhibition of maize root $\mathrm{H}^{+}$-ATPase by fluoride and fluoroaluminate complexes. Plant Physiology, v.108, p.241-246, 1995.

FAÇANHA, A.R.; FAÇANHA, A.; OLIVARES, F.L.; GURIDI, F.; SANTOS, G. de A.; VELLOSO, A.C.X.; RUMJANEK, V.M.; BRASIL, F.; SCHRISPEMA, J.; BRAZ-FILHO, R.; OLIVEIRA, M.A.; CANELLAS, L.P. Bioatividade de ácidos húmicos: efeitos sobre o desenvolvimento radicular e sobre a bomba de prótons da membrana plasmática. Pesquisa Agropecuária Brasileira, v.37, p.1301-1310, 2002.

GONZALES-VILA, F.J.; MARTIN, F.; RIOJ, C. del; FRUND, R. Structure characteristics and geochemical significance of humic acids isolated from three Spanish lignite deposits. Science of Total Environmental, v.117/118, p.335-343, 1992. 
GRIFFTH, T.; SCHNITZER, M. Analytical characteristics of humic and fulvic acids extracted from tropical volcanic soils. Soil Science Society of America Journal, v.39, p.861-867, 1975.

GUERRA, J.G.M.; SANTOS, G. de A. Métodos físicos. In: SANTOS, G. de A.; CAMARGO, F.A.O. (Ed.). Fundamentos da matéria orgânica do solo: ecossistemas tropicais e subtropicais. Porto Alegre: Genesis, 1999. p.267-292.

KONONOVA, M.M. Materia orgánica del suelo: su naturaleza, propiedades y métodos de investigación. Barcelona: Oikos-tau, 1982. $364 p$.

LU, X.Q.; HANNA, J.V.; JOHNSON, W.D. Source indicators of humic substances: an elemental composition solid state ${ }^{13} \mathrm{C} \mathrm{CP/}$ MAS NMR and Py-GC/MS study. Applied Geochemistry, v.15, p.1019-1023, 2000.

NARDI, S.; CONCHERI, G.; DELL'AGNOLA, G.; SCRIMIN, P. Nitrate uptake and ATPase activity in oat seedlings in the presence of two humic fractions. Soil Biology \& Biochemistry, v.23, p.833836, 1991.

ORLOV, D.S. Organic substances of Russian soils. Eurasian Soil Science, v.31, p.946-953, 1998.

PAGE, A.L. Methods of soil analysis. Madison: American Society of Agronomy, 1982. 1159p.
PRESTON, C.M. Applications of NMR to soil organic matter analysis: history and prospects. Soil Science, v.161, p.144-166, 1996.

SKJEMSTAD, J.O.; JANIK, L.J.; TAYLOR, J.A. Non-living soil organic matter: what do we know about it? Australian Journal of Experimental Agriculture, v.38, p.667-680, 1998.

STEELINK, C. Implications of elemental characteristics of humic substances. In: AIKEN, G.R.; McKNIGHT, D.M.; WERSHOW, R.L.; MACCARTHY, P. (Ed.). Humic substances in soil, sediment and water. New York: J. Wiley, 1985. p.457-476.

STEVENSON, F.J. Humus chemistry: genesis, composition, reactions. $2^{\text {nd }}$ ed. New York: J. Wiley, 1994. 443p.

TISDALE, S.L.; NELSON, W.L. Soil fertility and fertilizers. New York: Macmillan, 1966. 694p.

VAUGHAN, D.; MALCOLM, R.E. Influence of humic substances on growth and physiological process. In: VAUGHAN, D.; MALCOLM, R.E. (Ed.). Soil organic matter and biological activity. Dordrecht: Kluwer Academic, 1985. p.37-75.

VAUGHAN, D.; MALCOLM, R.E.; ORD, B.G. Influence of humic substances on biochemical processes in plants. In: VAUGHAN, D.; MALCOLM, R.E. (Ed.). Soil organic matter and biological activity. Dordrecht: Kluwer Academic, 1985. p.77-108. 